Conference Paper

\title{
Identification of Phenols and Triterpenoids Compounds in Michelia champaca for Treating Covid 19 Symptom by in Silico
}

\author{
Khoirin Maghfiroh *, Sri Widyarti, Sutiman B. Sumitro \\ ${ }^{1}$ Biology Department, Faculty of Mathematics and Natural Sciences Brawijaya University, Malang \\ Indonesia \\ ${ }^{2}$ Food and Science Technology Department, Faculty of Agriculture Yudharta University, Pasuruan \\ Indonesia
}

*Corresponding author:

E-mail: sutiman@ub.ac.id

\begin{abstract}
Michelia champaca is used by the community to treat mild diseases in the population. The plant Michelia champaca produces anti-inflammatory compounds. Some anti-inflammatory classes of compounds include Phenols and Triterpenoids. In disease prevention and treatment mechanics, COVID 19 in particular, the ability of anti-inflammatory compounds is very significant. Coronaviruses are viruses that were first described in 2019 attack the human respiratory system. Cough, a runny nose, and shortness of breath for fever are typical signs of viral infection. In defense mechanisms from coronaviruses, ACE2 is one of the inflammatory mediators used by the body. This study aimed to determine the potential of each group of Phenols and Triterpenoids compounds in Michelia champaca in binding ACE2 in Silico. The method used is docking molecule to find out the potential of anti-inflammatory compound groups. The ligands used in the study were Taraxerol, Taraxeron, Ferulic Acid, and Galic Acid. The protein used in the study was ACE2. The results showed that docking molecules for the Phenols and Triterpenoids groups separately showed that native ligand ACE2 could not bind to ligand copies of the Phenols and Triterpenoids groups. However, there are similar amino acid residues in ligand copy of Gallic acid with NAG. Gallic acid is a compound of phenols. The conclusion of this analysis is the complete ability of treatments and disease prevention in the Michelia Champaca plant as a result of COVID 19. However, the mechanism of interaction of plant compounds with proteins that play a part in the COVID 19 mechanism must still be demonstrated in vitro and in vivo in this research.
\end{abstract}

Keywords: Michelia champaca, COVID 19, in silico

\section{Introduction}

Some classes of anti-inflammatory agents, including phenols and terpenoids, play a key role in inflammatory mechanisms (Pérez-Cano \& Castell, 2016; Manosroi et al., 2013). Michelia champaca is the Malvaceae genus. The Malvaceae group is characterized by Taraxerol and Taraxerone compounds. A pair of Triterpenoids compounds are Taraxerol and Taraxeron (Peyeino et al., 2020). It is understood that Michelia champaca comprises both components based on the identification results. In both conventional and non-conventional medicine, Taraxerol and Taraxeron were used for various diseases, particularly those related to pathogens (Sharma \& Zafar, 2015). Besides Triterpenoids are used as anti-inflammatory compounds (Lacaille-Dubois \& Wagner, 2017). Michelia champaca also has antiinflammatory properties attributable to Phenols compounds (Nagavani \& Rao, 2010). Anti-inflammatory potential also exists for Phenols compounds, such as Gallic acid and Phenolic acid (Kahkeshani et al., 2019; Kumar \& Pruthi, 2014).

\section{How to cite:}

Maghfiroh, K., Widyarti, S., \& Sumitro, S. B. (2021). Identification of phenols and triterpenoids compounds in Michelia champaca for treating covid 19 symptom by in silico. $1^{\text {st }}$ Bioinformatics and Biodiversity Conference. NST Proceedings. pages 38-44. doi: 10.11594/ nstp.2021.0706 
Inflammation is due to the involvement of pathogens. The virus is one of the inflammatory pathogens in different tissues (Chen et al., 2018). Coronavirus (CoVs) is a virus that attacks human respiration (Corman et al., 2019). Patients with fever, dry toxin, and shortness of breath symptoms were detected in 2019. The virus is also known as Corona Virus Disease 2019 (COVID 19) (Unhale et al., 2020). When the virus stays, inflammatory reactions take place inside the body. Angiotensin Enzyme 2 (ACE2) conversion is one of the receptors of the human organism. The protein is related to the new Coronavirus (nCoV). The protein receptor ACE2 has good interactions with the virus. Respiratory, intestinal, testicular, and renal transmit receptors (Chen et al., 2020). The interaction between ACE2 receptors and protein-spike viruses mediates the entry of the virus into Epithelial cells of the host tropics in the respiratory system. IL-6 is one of the main mediators in the early stages of interaction between virus receptors. Proteolytic cleavage of the $S$ protein may also cause disease severity (Chatterjee et al., 2020). The link between Coronavirus and Toll-Like Receptor (TLR) can release IL-1 $\beta$ pro-inflammatory cytokines via caspase-1 (Conti et al., 2020).

ACE2 interactions with different compounds have been multiple studies with a potential as antioxidants, one of which is Phenols. Some Phenols, based on a study of virtual molecular docking, have the potential to attach to ACE2 in traditional plants. (Yu et al., 2020). Docking typically uses a single compound, but this research uses compound groups so that the position of each molecule in the receptor protéin field can be identified (Basu et al., 2020). Furthermore, the study of Michelia champaca for the group Triterpenoids like Taraxerol and Taraxerone has been done. For Taraxerol, it can be connected to proteins that play a role in inflammatory mediators. The similarity between amino acid residue and ligand copy in molecular docking studies is one factor affecting the relation of such compounds to the native ligand (Ur Rehman et al., 2013). Molecular docking studies are capable of being used as a basis in medicine and disease therapy manufacturing. Also, coronavirus-caused diseases (COVID 19), a new pathogen, should be researched in the analysis of natural compounds that help the disease preventive and treatment process. This study aimed to assess the potential of each group of Phenols and Triterpenoids compounds for ACE2. This research used ACE2 as a protein receptor. This research has explored native ligand-protein receptors and ligand copy groups of compounds. The study findings are focused on the binding energy and amino acid residue similarity.

\section{Material and Methods Protein Preparation}

Angiotensin-Converting Enzyme 2 was the protein used in this study (ACE2) (PDB id: 6vw1). Protein from the http:/www.rcsb.org/ web site. 3-Dimensional protein structure to be used downloaded and then prepared with the removal of water molecules and other compounds so that there are only proteins. Protein preparation using Discovery Studio. The pre-prepared protein is then stored in PDP format.

\section{Molecule preparation}

The molecules used in this study were obtained from the web http:/pubchem.ncbi.nlm.nih.gov in GDP format. Three classes of compounds comprise the molecules used. The first are compounds such as Phenols and Triterpenoids. The compound is available from the PubChem web. Phenols were Gallic Acid (PubChem id:370) and Ferulic Acid (PubChem id:445858) used in this study. The Triterpenoids used in this study consisted of Taraxerol (PubChem id: 92097) and Taraxerone (PubChem id: 92785).

\section{Molecular docking analysis}

Molecular docking analysis using AutoDock software version 4.2.6. 20-23 Grid map with $60 \times$ $60 \times 60$ points created and lattice point distance is $0.375^{\circ} \mathrm{A}$. 24 The Lamarckian genetic algorithm (LGA), considered one of the best docking methods available in AutoDock, is the parameter for the 
LGA specified as follows: a maximum number of 250,000 energy evaluations and a maximum number of 27,000 generations (Iman et al., 2015). Binding energy native ligand and ligand copy of receptor protein based on RMSD Value result after docking process with PyRx. Similarities in amino acid residues were identified using Discovery Studio (DS) software.

\section{Results and Discussion}

Based on reference studies, Michelia champaca plant compounds are described. This research included three classes of compounds. Table 1 indicates the compound.

Table 1. Potential compound group identification on Michelia Champaca

\begin{tabular}{lll}
\hline Group & Compounds & Reference \\
\hline Phenols & Gallic Acid & (Ahmad et al., 2011) \\
& Ferulic Acid & (Ananthi \& Anuradha, 2015) \\
Triterpenoids & Taraxerol & (Peyeino et al., 2020) \\
& Taraxeron & (Wang et al., 2009) \\
\hline
\end{tabular}

Data were produced using DS software in the form of images based on defined molecular docking performance.

\section{Phenols}

Here are the results of virtual screening with ACE2 receptor protein for Gallic acid and Ferulic acid. The picture below shows that the ligand copy compounds of the Phenol group are known as the power of native ligand-protein receptor ACE2.

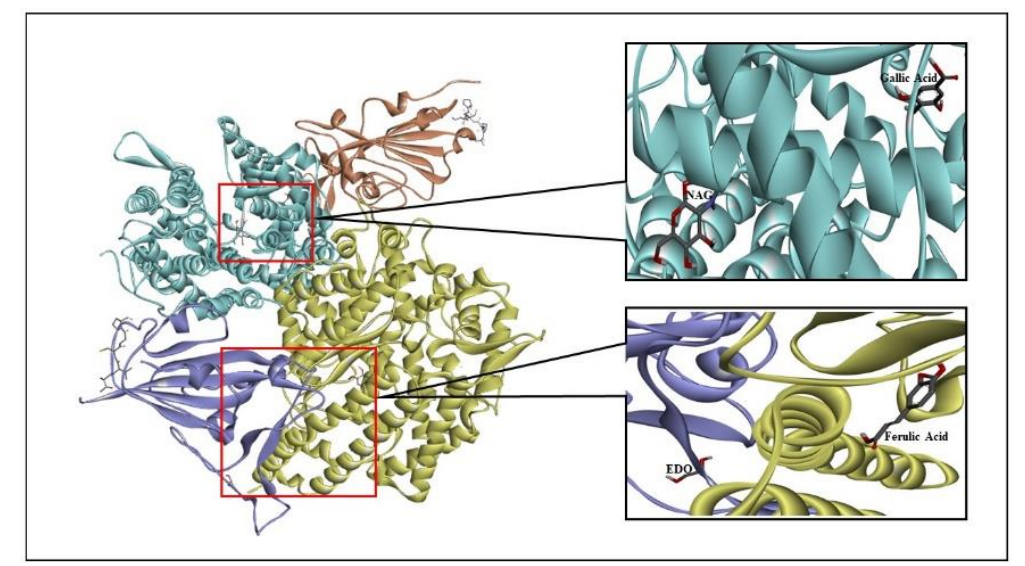

Figure 1. Molecular docking ACE2 with ferulic acid and gallic acid

Figure 1 indicates that EDO and Ferulic Acid are known as the native ligand in different domains. This is not the case for Gallic Acid. The ACE2 protein receptor from Native Ligand is inside the same domain as Gallic Acid from Ligand Copy.

\section{Triterpenoids}

Taraxerol and Taraxeron were the Michelia champaca compounds in this analysis. Both molecules were simultaneously tested for EDO and NAG, native ligand-receptor proteins. 


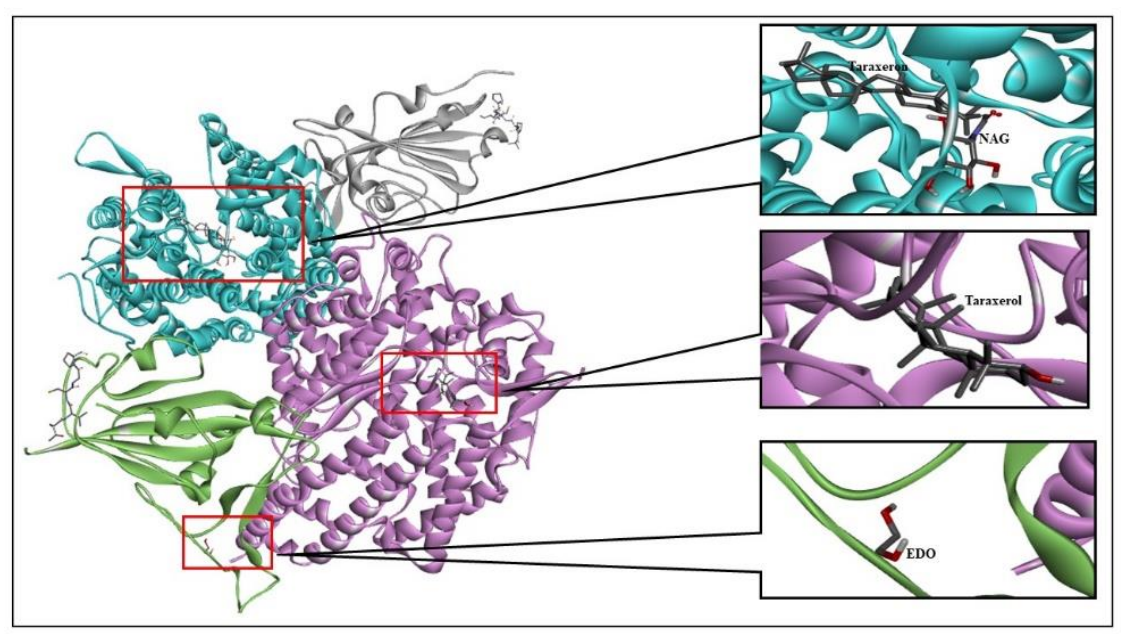

Figure 2. Molecular docking ACE2 with taraxeron dan taraxerol

Based on the data from Fig.3, the Taraxeron ligand copy is in the same domain as NAG, while Taraxerol is in a different region. EDO is then a native ligand in another domain than the Taraxero and the Taraxeron. Differences in ligand copy groups of Phenols, Flavonoids, and Triterpenoids with native ligands to ACE2 receptor proteins are caused by Binding Energy - respectively ligand copy and native ligand to receptor proteins. Binding Energy ligand a copy of protein can be influenced by amino acid acids between native ligand-protein receptor ACE2 (Table 2) and ligand copy. This is based on the results of the research contained in table 3.

Table 2. Binding energy native ligand protein receptor ACE2

\begin{tabular}{lll}
\hline Native Ligand & Binding Energy $(\mathrm{Kcal} / \mathrm{mol})$ & Amino Acid Residue \\
\hline NAG & $-5,7$ & ASP 350, ASP 382, ALA 348, \\
& & TRP 349, HIS 401, HIS 378, \\
& TYR 385, ASN 394, PHE \\
& $\mathbf{3 9 0}$ ARG 393, PHE 40 \\
\hline EDO & ARG 454, ARG 457, ASP 467, \\
& PHE 456, SER 469, GLU 471, \\
& PRO 491, THR 470
\end{tabular}

Table 3. Michelia champaca compound plant group energy binding to ACE2 protein receiver

\begin{tabular}{|c|c|c|c|c|}
\hline Compounds & Ligand & $\begin{array}{l}\text { Binding } \\
\text { (Kcal/mol) }\end{array}$ & Energy & Amino Acid Residue \\
\hline \multirow[t]{7}{*}{ Triterpenoids } & \multirow[t]{5}{*}{ Taraxerol } & \multirow[t]{5}{*}{$-9,6$} & & SER 128, LEU 143, TYR \\
\hline & & & & 127, LEU 144, ASN \\
\hline & & & & 149, PHE 504, ASP \\
\hline & & & & 269, ARG 273, PHE \\
\hline & & & & 274, TRP 271, HIS 345 \\
\hline & \multirow[t]{3}{*}{ Taraxeron } & \multirow[t]{3}{*}{$-9,4$} & & LEU 370, PRO 346, HIS \\
\hline & & & & 505, PHE 274, SER \\
\hline To be continued & & & & 409, ASP 367, THR \\
\hline
\end{tabular}


445, ARG 273, HIS 345,

TYR 515, ZN 703, THR

347, GLU 375, ARG

518, THR 371

\begin{tabular}{lll}
\hline Phenols & $-6,2$ & THR 371, GLU 406, \\
& & SER 409, ILE 446, GLN \\
& 442, LYS 441, THR \\
& 445, LEU 370, ASP \\
& & 367, HIS 374 \\
\hline Asam Galat & $-5,6$ & LEU 391, PHE 390, \\
& GLY 352, PHE 40, LEU \\
& 351, ASP 350, ARG \\
& $\mathbf{3 9 3 , \text { ASN 394 }}$ \\
\hline
\end{tabular}

Based on the study results in Table 3, gallic acid -5.6kcal per mol and NAG-5.7kcal/mol binding strength is well established. In comparison to the energy binding value, Gallic acid nearest to another binding energy ligand copy used in this analysis is higher compared to NAG. There are also parallels between the ligand copy of Gallic acid and the native ligand NAG for some of the same amino acid residues.

\section{Discussion}

The detection of an active compound's ability to defend against target proteins can be known by recognizing amino acid residues, which are very significant in the ligands binding with receptor proteins. The binding energy between ligands and target proteins may affect Ligand amino acid residues of receptor proteins (Mirza \& Froeyen, 2020). This is consistent with the research findings presented in Tables 2 and 3 . The binding energy ligand copy and native ligand will affect the similarity of amino acid residues. ASP 350, ARG 393, ASN 394, ASP 394, and others are amino acid residues. The similarity between compounds and active sites on a target protein is of good binding importance as ligand copies of the same amino acid residues in proteins can be recognized by DNA in proteins (Luscombe \& Thornton, 2002). Compound molecules may be binding on the active target protein sites to pave the way for COVID 19 symptom therapy.

Currently, COVID 19 therapy is in the stages of disaster drug development. Several possible compounds based on silico studies can be defined to help the process. Several anti-inflammatory compound groups that can bind to the target protein were examined. The receptor protein ACE2 has been commonly used as a target in COVID 19 therapy drug findings (Gupta et al., 2020). Compounds for COVID 19 are anti-inflammatory Compounds (Pintać et al., 2018). Molecular docking experiments are performed to demonstrate the mechanism of the COVID 19 receptor protein compounds for certain anti-inflammatory compounds. Phenol compounds such as Gallic acid can inhibit COVID 19 activity based on in silico studies (Khaerunnisa et al., 2020).

Antiviral compounds include Triterpenoids and Phenols have aromatic compounds with antiviral potential (Wang et al., 2015; Suárez et al., 2010). The compound is investigated by traditional plants in medicine (Lin et al., 2014). Michelia champaca is a common plant used by the community to overcome infectious diseases. In the treatment of infection, the anti-inflammatory properties of plant (Raja \& Koduru, 2014). COVID 19 is a virus that infects the breathing system (Shereen et al., 2020). 


\section{Conclusion}

The results have shown that active compounds are capable of binding to the receptor proteins' active sites. The binding force in the Gallic acid ligand copy and the Native Ligand NAG is demonstrated by the binding energy. The residues of the amino acids of the two ligands also help the similarity. In Michelia champaca the active compound can treat COVID 19 symptoms. These findings can be used in in vitro and in vivo trials to find successful therapy for COVID 19.

\section{Acknowledgment}

This work was supported by grants from the Research Grants for Professor from Faculty of Mathematics and Natural Sciences, Brawijaya University, FY 2019 and 2020.

\section{References}

Ahmad, H., Mishra, A., Gupta, R., \& Saraf, S. A. (2011). Determination of gallic acid in Michelia champaca L. (Champa) leaves and stem bark by HPTLC. Der Pharmacia Lettre.

Ananthi, T., \& Anuradha, R. (2015). Determination of phenolic compounds in flowers of Michelia Champaca l. By HPLC analysis. International Journal of Pharmaceutical Sciences Review and Research, 33(2), 158-165.

Basu, A., Sarkar, A., \& Maulik, U. (2020). Molecular docking study of potential phytochemicals and their effects on the complex of SARSCoV2 spike protein and human ACE2. Scientific Reports, 10, 17699. https://doi.org/10.1038/s41598-020-74715-4

Chatterjee, S. K., Saha, S., \& Munoz, M. N. M. (2020). Molecular Pathogenesis, Immunopathogenesis and Novel Therapeutic Strategy Against COVID-19. In Frontiers in Molecular Biosciences. https://doi.org/10.3389/fmolb.2020.00196

Chen, L., Deng, H., Cui, H., Fang, J., Zuo, Z., Deng, J., Li, Y., Wang, X., \& Zhao, L. (2018). Inflammatory responses and inflammationassociated diseases in organs. In Oncotarget, 9(7204-7218. https://doi.org/10.18632/oncotarget.23208

Chen, Y., Guo, Y., Pan, Y., \& Zhao, Z. J. (2020). Structure analysis of the receptor binding of 2019-nCoV. Biochemical and Biophysical Research Communications, 525(1), 135-140. https://doi.org/10.1016/i.bbrc.2020.02.071

Conti, P., Ronconi, G., Caraffa, A., Gallenga, C. E., Ross, R., Frydas, I., \& Kritas, S. K. (2020). Induction of pro-inflammatory cytokines (IL1 and IL-6) and lung inflammation by Coronavirus-19 (COVI-19 or SARS-CoV-2): anti-inflammatory strategies. In Journal of biological regulators and homeostatic agents, 34(2), 327-331. https://doi.org/10.23812/CONTI-E

Corman, V. M., Lienau, J., \& Witzenrath, M. (2019). Coronaviruses as the cause of respiratory infections. Internist, 60(11), $1136-1145$. https://doi.org/10.1007/s00108-019-00671-5

Gupta, A., Madhavan, M. V., Sehgal, K., Nair, N., Mahajan, S., Sehrawat, T. S., Bikdeli, B., Ahluwalia, N., Ausiello, J. C., Wan, E. Y., Freedberg, D. E., Kirtane, A. J., Parikh, S. A., Maurer, M. S., Nordvig, A. S., Accili, D., Bathon, J. M., Mohan, S., Bauer, K. A., ... Landry, D. W. (2020). Extrapulmonary manifestations of COVID-19. In Nature Medicine. 26(7), 113-117. https://doi.org/10.1038/s41591-020-0968$\underline{3}$

Iman, M., Saadabadi, A., \& Davood, A. (2015). Molecular docking analysis and molecular dynamics simulation study of ameltolide analogous as a sodium channel blocker. Turkish Journal of Chemistry, 39(2), 306-316. https://doi.org/10.3906/kim-1402-37

Kahkeshani, N., Farzaei, F., Fotouhi, M., Alavi, S. S., Bahramsoltani, R., Naseri, R., Momtaz, S., Abbasabadi, Z., Rahimi, R., Farzaei, M. H., \& Bishayee, A. (2019). Pharmacological effects of gallic acid in health and disease: A mechanistic review. Iranian Journal of Basic Medical Sciences, 22(3), 22-237. https://doi.org/10.22038/ijbms.2019.32806.7897

Khaerunnisa, S., Kurniawan, H., Awaluddin, R., \& Suhartati, S. (2020). Potential Inhibitor of COVID-19 Main Protease ( M pro ) from Several Medicinal Plant Compounds by Molecular Docking Study. Preprints, $20.2020030226 . \quad$ doi: 10.20944/preprints202003.0226.v1

Kumar, N., \& Pruthi, V. (2014). Potential applications of ferulic acid from natural sources. In Biotechnology Reports, 4 , 86-93. https://doi.org/10.1016/j.btre.2014.09.002

Lacaille-Dubois, M. A., \& Wagner, H. (2017). New perspectives for natural triterpene glycosides as potential adjuvants. Phytomedicine, 37, 49-57. https://doi.org/10.1016/i.phymed.2017.10.019

Lin, L. T., Hsu, W. C., \& Lin, C. C. (2014). Antiviral natural products and herbal medicines. Journal of Traditional and Complementary, 4(1), 24-25. Medicine. https://doi.org/10.4103/2225-4110.124335

Luscombe, N. M., \& Thornton, J. M. (2002). Protein-DNA interactions: Amino acid conservation and the effects of mutations on binding specificity. Journal of Molecular Biology, 320(5), 991-1109. https://doi.org/10.1016/S0022-2836(02)00571-5 
Manosroi, A., Jantrawut, P., Ogihara, E., Yamamoto, A., Fukatsu, M., Yasukawa, K., Tokuda, H., Suzuki, N., Manosroi, J., \& Akihisa, T. (2013). Biological activities of phenolic compounds and triterpenoids from the Galls of Terminalia chebula. Chemistry and Biodiversity, 10(8), 1448-1463. https://doi.org/10.1002/cbdv.201300149

Mirza, M. U., \& Froeyen, M. (2020). Structural elucidation of SARS-CoV-2 vital proteins: Computational methods reveal potential drug candidates against main protease, Nsp12 polymerase and Nsp13 helicase. Journal of Pharmaceutical Analysis, 10(4), 320-328. https://doi.org/10.1016/i.jpha.2020.04.008

Nagavani, V., \& Rao, T. R. (2010). Evaluation of antioxidant potential and identification of polyphenols by RP-HPLC in Michelia champaca flowers. Adv Biol Res.

Pérez-Cano, F. J., \& Castell, M. (2016). Flavonoids, inflammation and immune system. In Nutrients, 8(10), 659. https://doi.org/10.3390/nu8100659

Peyeino, J. H., Djomkam, H. L. M., Kenmogne, S. B., Langat, M. K., Isyaka, S. M., Tsopgni, W. D. T., Wansi, J. D., Kamdem Waffo, A. F., Sewald, N., \& Vardamides, J. C. (2020). First report of compounds from an Ancistrocarpus species: Triterpenoids from A. densispinosus Oliv. (Malvaceae). Natural Product Research. https://doi.org/10.1080/14786419.2020.1782408

Pintać, D., Majkić, T., Torović, L., Orčić, D., Beara, I., Simin, N., Mimica-Dukić, N., \& Lesjak, M. (2018). Solvent selection for efficient extraction of bioactive compounds from grape pomace. Industrial Crops and Products, 111(2018), 379-390. https://doi.org/10.1016/j.indcrop.2017.10.038

Raja, S., \& Koduru, R. (2014). A Complete Profile on Michelia Champaca - Traditional Uses, Pharmacological Activities and Phytoconstituents. International Journal for Pharmaceutical Research Scholars (IJPRS ), 3(2), 496-504.

Sharma, K., \& Zafar, R. (2015). Occurrence of taraxerol and taraxasterol in medicinal plants. In Pharmacognosy Reviews, 9(17), 19. https://doi.org/10.4103/0973-7847.156317

Shereen, M. A., Khan, S., Kazmi, A., Bashir, N., \& Siddique, R. (2020). COVID-19 infection: Origin, transmission, and characteristics of human coronaviruses. In Journal of Advanced Research, 24, 91-98. https://doi.org/10.1016/i.jare.2020.03.005

Suárez, B., Álvarez, Á. L., García, Y. D., Barrio, G. del, Lobo, A. P., \& Parra, F. (2010). Phenolic profiles, antioxidant activity and in vitro antiviral properties of apple pomace. Food Chemistry, 120(1), 339-342. https://doi.org/10.1016/i.foodchem.2009.09.073

Unhale, S. S., Ansar, Q. B., Sanap, S., Thakhre, S., \& Wadatkar, S. (2020). a Review on Corona Virus ( Covid-19 ). World Journal of Pharmaceutical and Life Sciences, 6(4), 109-115.

Ur Rehman, U., Shah, J., Ahmed Khan, M., Raza Shah, M., Ishtiaq, \& Khan, I. (2013). Molecular docking of taraxerol acetate as a new COX inhibitor. Bangladesh Journal of Pharmacology. 8(2), 194-7. https://doi.org/10.3329/bjp.v8i2.14167

Wang, H. M., Lo, W. L., Lu, Y. C., Yeh, Y. T., Huang, L. Y., Huang, J. C., \& Chen, C. Y. (2009). Chemical constituents from the leaves of Michelia compressa var. formosana. Chemistry of Natural Compounds, 45(6), 931-933. https://doi.org/10.1007/s10600-010-9463-2

Wang, L., Yang, R., Yuan, B., Liu, Y., \& Liu, C. (2015). The antiviral and antimicrobial activities of licorice, a widely-used Chinese herb. In Acta Pharmaceutica Sinica B, 5(4), 310-315. https://doi.org/10.1016/j.apsb.2015.05.005

Yu, J. wang, Wang, L., \& Bao, L. dao. (2020). Exploring the active compounds of traditional Mongolian medicine in intervention of novel coronavirus (COVID-19) based on molecular docking method. Journal of Functional Foods., 71, 104016. https://doi.org/10.1016/j.jff.2020.104016 